Retraction

\title{
Retraction: Khan, N.U. et al. Spatiotemporal Analysis of Tourists and Residents in Shanghai Based on Location-Based Social Network's Data from Weibo. ISPRS Int. J. Geo-Inf. 2020, 9, 70
}

\section{IJGI Editorial Office}

MDPI, St. Alban-Anlage 66, 4052 Basel, Switzerland; ijgi@mdpi.com

Received: 19 November 2020; Accepted: 30 November 2020; Published: 3 December 2020

The IJGI Editorial Office has been made aware that the published paper [1] has a potential plagiarism issue with the published paper [2]. It seems that the authors of [1] took the paper by $\mathrm{Su}, \mathrm{X}$. et al. [2] as a template and modified it for the Shanghai case with Shanghai data. Therefore, the IJGI Editorial Office has taken the decision to retract [1] in order to preserve academic integrity. We apologize to the readers of IJGI and to the authors of the previous work. The decision to retract has been taken in agreement with the authors of [1]. MDPI is a member of the Committee on Publication Ethics and takes its responsibility to enforce strict ethical policies and standards very seriously. To ensure the addition of only high-quality scientific works to the field of scholarly publication, the present paper [1] was retracted. The article was retracted with the agreement of all authors. We apologize to the readership of IJGI for any inconvenience caused.

\section{References}

1. Khan, N.U.; Wan, W.; Yu, S. Spatiotemporal Analysis of Tourists and Residents in Shanghai Based on Location-Based Social Network's Data from Weibo. ISPRS Int. J. Geo-Inf. 2020, 9, 70. [CrossRef]

2. Su, X.; Spierings, B.; Dijst, M.; Tong, Z. Analysing trends in the spatio-temporal behaviour patterns of mainland Chinese tourists and residents in Hong Kong based on Weibo data. Curr. Issues Tour. 2020, 23, 1542-1558. [CrossRef]

Publisher's Note: MDPI stays neutral with regard to jurisdictional claims in published maps and institutional affiliations.

(C) 2020 by the author. Licensee MDPI, Basel, Switzerland. This article is an open access article distributed under the terms and conditions of the Creative Commons Attribution (CC BY) license (http://creativecommons.org/licenses/by/4.0/). 